\title{
Kernos
}

Revue internationale et pluridisciplinaire de religion grecque antique

6 | 1993

Varia

\section{Uniformity and Change in Minoan and Mycenaean Religion}

\author{
Bernard C. Dietrich
}

\section{OpenEdition \\ Journals}

Electronic version

URL: http://journals.openedition.org/kernos/540

DOI: $10.4000 /$ kernos.540

ISSN: 2034-7871

\section{Publisher}

Centre international d'étude de la religion grecque antique

\section{Printed version}

Date of publication: 1 January 1993

Number of pages: 113-122

ISSN: 0776-3824

\section{Electronic reference}

Bernard C. Dietrich, « Uniformity and Change in Minoan and Mycenaean Religion », Kernos [Online], 6 | 1993, Online since 07 April 2011, connection on 19 April 2019. URL : http:// journals.openedition.org/kernos/540; DOI : 10.4000/kernos.540 


\section{UNIFORMUTY AND CHANGE}

\section{IN MINOAN AND MYCENAEAN RELIGION}

Two issues, that remain very much alive to-day, concern the relationship of Minoan with Mycenaean religion, and the extent of the survival of Mycenaean into Greek religion. The first question is rarely addressed nowadays, because it is generally assumed that irreconcilable differences separated the Minoans, with their central figure of a goddess, from the later, more visibly Indo-European and male dominated mainland culture.

The assumption is based on chronological, ethnic and on linguistic grounds and reinforced by almost half a century of scholarly tradition since Nilsson's recantation of his earlier view concerning one common Minoan/Mycenaean religion. Now Minoan cults are usually traced diachronically from site to site beginning with the Early Minoan tholos to the sophisticated palace culture of the Middle and Late Bronze Age ${ }^{1}$. Religious forms that emerge from the archaeology of the various periods produce a distinctive picture of the geography and architecture of cult. But the substance of such cults remains obscure, as does their distribution across the island.

Minoan religion is a pretty comprehensive term ${ }^{2}$ to describe a collection of cults which seem regional and community based, although there may have been patterns which were repeated throughout the island in the manner of the polis cults in archaic and classical Greece. Again the usual division into cave, peak and rural, that is outside, shrines and inside domestic cults needs revising on two counts, firstly as an indicator of some kind of sequential progression from primitive to developed palatial cult forms, and secondly as a clearly defined demarcation of cult type that was confined to one particular shrine.

Caves were certainly used for habitation and burial in Neolithic and Early Minoan, but only Psychro (Dikte), Skoteino, Kamares, Trapeza

1 W. Pötscher's book is a notable exception, Aspekte und Probleme der minoischen Religion, Hildesheim, 1990.

2 Such collective titles have been questioned by C. RENFrEw, The Archaeology of Cult: The Sanctuary at Phylakopi, London, 1985, p. 394. 
and the Idaean Cave show clear evidence of cult between MMI \& IIIA ${ }^{3}$. Cave sanctuaries did not become popular until the final Minoan phase when they succeeded peak cult whose floruit lay in Middle Minoan ${ }^{4}$. In other words, although both predated the palaces, they did not come into vogue before that period and continued strongly in post-palatial times. Peak and cave cult were related and revolved about a central fire ritual and sacrifice ${ }^{5}$. In tradition these were associated with rites of death and renewal ${ }^{6}$; but votives differed from cave to cave ${ }^{7}$ suggesting local variations of cult. Also peak cult is a misnomer for sites with relatively modest elevations by Cretan standards ${ }^{8}$ : they were far from isolated as a rule, but like cult caves generally oriented towards community centre or palace. Cult structures, that is shrines or stores, on these sites were built at the same time as the expanded Second Palaces ${ }^{9}$, superseding an open temenos with altar and thick layers of sacrificial ash ${ }^{10}$.

There was a relationship between outside sanctuary and palace as a community's focal point, but not necessarily as its religious centre. The

3 Full bibliographies in B. RUTKowsKI, The Cult Places of the Aegean, Yale UP, 1986, p. $69 \mathrm{n}^{\circ} 11$; p. $70 \mathrm{n}^{\circ} 23$; p. $71 \mathrm{n}^{\circ} 26$; $\mathrm{n}^{\circ} 29$. Professor J. Sakellarakis privately informed me that he has found evidence of cult in the cave in Neolithic.

4 RUTKowski, Cult Places, p. 47-71; 73-98.

5 P.S. BARshinger, A Structural Analysis of the Ritual Areas of MMIII/LMI Minoan Crete, thesis 1987, UMI 1990, p. 55-56.

6 B.C. DiETRICH, Origins of Greek Religion, Berlin, 1974, ch. II; ID., Tradition in Greek Religion, Berlin, 1986, p. 30-31 n. 190.

7 RUTKowski, ibid.; BARShINGER, Struct. Analysis, p. 56-59.

8 Between $600 \mathrm{~m}$ and $800 \mathrm{~m}$ as a rule, see A.A.D. Peatfinld, Palace and Peak: the political and religious relationship between palaces and peak sanctuaries, in The Function of the Minoan Palaces, Procs. of the 4th Intern. Sympos. at the Swedish Institute in Athens 1984, R. HÄGG \& N. MARINATOS eds., Stockholm, 1987, maps on p. 89-93; Minoan Peak Sanctuaries: History and Society, in OAth, 18 (1990), p. 119.

9 PEATFIELD, in OAth, 18 (1990), p. 124;126.

10 E.g. Mt. Juktas, A. KARETSOU, The peak sanctuary on Mt. Juktas, in Sanctuaries and Cults of the Aegean Bronze Age, Procs. of the 1st Intern. Sympos. at the Swedish Institute in Athens 1980, R. HäGG \& N. MARINATOS eds., Stockholm, 1981, p. 137-153. 
palace was a social rather than religious phenomenon ${ }^{11}$ : it demonstrated the community's prosperity but was built into a preexisting network of roads and public courts. Cult occurred in these open spaces, as it had since EMII about the tombs of Mochlos and the Mesara and in the paved courts of Gournia and Vasiliki ${ }^{12}$. The Second Palaces encroached upon this space at the western end of the court, interiorising part of the cult area as at Knossos, for example, but not usually cutting off the connection with the central court altogether ${ }^{13}$. The Lustral Basin and Pillar Crypt, that is two characteristic so-called 'domestic' sanctuaries, did not originate as integral parts of the palace complex, but at the beginning of MM they could be found separately in Quartier Theta at Mallia, or indeed in a tomb as at Apesokari. The third type in this category, the Bench Sanctuary, already existed in Myrtos in EMII, possibly also associated with an open space ${ }^{14}$.

Except for Knossos, palaces disappeared at the end of LMI; peak cults flourished and faded away concurrently with them ${ }^{15}$. Worship lived on in caves or reverted to open areas. According to the prevailing view, the destruction of the palaces and large houses at about $1400 \mathrm{BC}$ marked the beginning of Mycenaean domination in Crete. The new masters in this account, chose Knossos as their administrative centre ${ }^{16}$, brushed aside the Minoan shrines and introduced their own distinctive architectural style in the form of the megaron. The Knossian Throne Room lived on,

11 J. F. CHERRY links peak sanctuaries to an hierarchical ruling elite of the first palaces, Generalisation and the archaeology of the state, in Social organisation and settlement (BAR Int. Series, suppl. 47), D. Green, C. HazElgrove, M. SpRIGGS eds., Oxford, 1978, p. 411-437; cf. The Emergence of the State in the Prehistoric Aegean, in PCPhS (1984), p. 18-48; Politics and Palaces: some problems in Minoan state formation, in Peer polity interaction and sociopolitical change, C. RENFREw \& J. F. CHERRY eds., Cambridge, 1986, p. 19-45.

12 S. Damiani Indelicato, Piazza Publica e Palazzo nella Creta Minoica, Rome, 1982; D. Preziosi, Minoan Architectural Design: Formation and Signification, Berlin, 1983; BARSHINGER, Struct ., p. 43; 79.

13 BARSHINGER, Struct., p. 105; 106; 121.

14 Myrtos Room 92 of the complex, P. WARREN, Myrtos: an Early Bronze Age Settlement in Crete, Oxford, 1972, p. 85-87. On the LB and Pillar Crypt see G.C. Gesell, Town, Palace and House Cult in Minoan Crete, Göteborg, 1985, p. 1415; B ARShinger, Struct., p. 106; 119; IndeliCATo, Piazza, p. 117.

15 BARshinger, Struct., p. 152.

16 E.g. E. Hallager, The Mycenaean Palace at Knossos: Evidence for Final Destruction in the IIIB Period, Stockholm, 1977, p. 15; 71. 
because it is said to have recalled the megara of Tiryns and Mycenae. But earlier models in the Minoan villas of Nirou Khani and Vathypetro ${ }^{17}$ make this unlikely. Political change does not necessarily presuppose religious innovation.

A central open space had always been an important part of Aegean sanctuaries. The fashion spread from the east, like that of building tripartite shrines, it endured for over two millennia in Cretan Syme and set the standard for archaic sanctuaries at Kourion and elsewhere in ultra conservative Cyprus ${ }^{18}$. In this history the palace constitutes a confusing element, because it temporarily replaced an older arrangement for socio-political rather than religious reasons ${ }^{19}$. If true, this resolves the apparent clash between what is generally seen as the palacefocal cult of Middle until Late Minoan IIIA (Knossos) and the more primitive post-palatial arrangement of the open cult area and Bench Sanctuary.

Typical examples are the Piazzale dei Sacelli with Building $\mathrm{H}$ at Hagia Triada ${ }^{20}$, and the West and East Shrines at Phylakopi on Melos $^{21}$. In Greece at Mycenae the Cult Centre with temple or bench sanctuaries about open courts actually seemed to compete with palace cult in Late Helladic III ${ }^{22}$. In Tiryns, too, shrines and open court in the 'Unterburg' flourished subsequently to the more opulent palace installations on the upper acropolis. The excavator interpreted the shift as the

17 BARSHINGER, Struct., p. 153.

18 DiETRICH, Tradition, p. 126-129; 135; 136; ID., Aegean Sanctuaries: Forms and Function, in New Perspectives in Early Greek Art, Washington, 1991, p. 142. The sanctuary at Syme had some 'palatial features' in its earliest buildings but retained an open air cult from 1700 to the 5 th century B.C. when roofed shrines were introduced, A. Lebessi-P. MuHLY, Aspects of Minoan Cult. Sacred Enclosures. The Evidence from the Syme Sanctuary (Crete), in AA (1990), p. $315 ; 335 ; 336$.

19 For the most recent discussion of social forces in Minoan religion see L. PRESS, On the Creators of the Minoan Places of Worship, in Klio, 73 (1991) p. 5-19.

20 G ESELL, Town, p. 41; 57-59; p. $74 \mathrm{n}^{\circ} 15 ;$ p. $76 \mathrm{n}^{\circ} 17$.

21 RENFREW, Phylakopi, 71-87.

22 On the Cult Centre see G.E. Mylonas, The Cult Centre of Mycenae, in Proceedings of the British Academy, 67 (1982), p. 320; E. FRENCH, Cult Places at Mycenae, in Sanctuaries, p. 4148; K.P. KonTORLIS, Mycenaean Civilization. Mycenae, Tiryns, Asine, Midea, Pylos, Athens, 1985, p. I-v; 50; 62-63, for the lay-out and dates. 
sign of a meaner popular cult replacing the older 'Staatsreligion'23. However, cult in the lower fortress at Tiryns probably predated the destruction of the palace in LHIIIB2, and in Mycenae both Cult Centre and palace perished together in LHIIIB, so that there is no need to look for a separate cult in the palace megaron ${ }^{24}$.

The same applies to the different modes of ceremonial procession which, judging from frescoes in Knossos and Pylos, moved towards an interior room in the palace but was outward bound from the citadel to the Cult Centre at Mycenae ${ }^{25}$. The contrast was due to changing fashions rather more than to cult content, one suspects, and politically motivated, or it indicated the hierarchical system of an exclusive palace society. For similar reasons the critical phase of blood sacrifice was also moved inside the palace, out of sight of everyone, explaining the puzzling conflict with subsequent practice when cult and ritual became more accessible to all. However, the potent message of renewal stayed the same ${ }^{26}$.

The end of the palaces at Knossos in IIIA and Mycenae in IIIB was accompanied by a transformation of sacred iconography. A novel kind of cult assemblage became virtually ubiquitous in Aegean shrines consisting of an anthropomorphic divine pair of god and goddess.

23 K. KILIAN, Zeugnisse Mykenischer Kultausübung in Tiryns, in Sanctuaries, p. 49-58; on the Mycenae Cult Centre see E. FrENCH, Cult Places at Mycenae, in Sanctuaries, p. 41-48; cf. K.P. KonTORLIS, Mycenaean Civilization. Mycenae, Tiryns, Asine, Midea, Pylos, Athens, 1985, p. I-v; 50; 62-63, for the lay-out and dates of both sites.

24 Mylonas and Renfrew argue against any kind of cult having occurred in the megaron of the Mycenaean palace, which seems exaggerated in view of the survival of the Throne Room in Knossos, G.E. MyLonAs, The Cult Centre of Mycenae, in Procs. British Academy, 67 (1982), p. 320; RENFrew, Phylakopi, p. $401 ; 403$.

25 Grand Staircase Fresco, M.A.S. CAMERON, New Restorations of Minoan Frescoes from Knossos, in BICS, 17 (1970), p. 163-166; R. HÄGG, Pictorial Programmes in Minoan Palaces and Villas, in L'Iconographie Minoenne, P. DARQUe \& J.C. Poursat eds., BCH Suppl., 11 (1985), p. 210-212; A. Evans, $P M$ vol. 2, Pls. 119;125.

26 On Minoan sacrificial practice see N. MARINATOS, Minoan Sacrificial Ritual. Cult Practice and Symbolism, Stockholm, 1986 (Acta Inst. Ath. Regni Sueciae 8, 9), especially p. 19-21; 30; B.C. DIETRICH, The Instrument of Sacrifice, in Early Greek Cult Practice (Procs. 5th Intern. Symposium at the Swedish Institute in Athens, 26-29 June 1986),Stockholm, 1988, p. 35-40; A Minoan Symbol of Renewal, in Journal of Prehistoric Religion, 2 (1988), p. 12-24. 
Dedications in the West Shrine at Phylakopi actually emphasized a division between male and female votives ${ }^{27}$. With this practice one might compare the sets of complementary masculine and feminine theophoric names like diwijo - diwija and posedao and posidaeja in the Knossian and Pylian documents ${ }^{28}$. Archaeologists argue that these are signs of the collapse of the specialised Minoan palace system, heralding the arrival of a new culture at that point rather than after the end of the Bronze $\mathrm{Age}^{29}$. In other words, the Mycenaeans are perceived as more profoundly disruptive of Minoan and Bronze Age Aegean religious traditions than any other cause during the ensuing Dark Age which more or less directly integrated with the evolving Hellenic culture ${ }^{30}$.

However, with cult in the Throne Room under Mycenaean control at Knossos, the neighbouring peak cult continued without break on Juktas, and so did the cult in Syme to which Knossos went on sending its votive gifts. In the sanctuary's sacred enclosure the Mycenaeans blithely took over Minoan processional and sacrificial ritual which they handed on to their descendants in Geometric and Archaic Greece ${ }^{31}$. The palace's disappearance did not affect the main religious symbols such as the horns of consecration, double axe, bird, bull and so on which survived in extra-palatial shrines ${ }^{32}$. Apart from physical survivals of the Minoantype bench sanctuary at $A \sin ^{33}$, and what appear to be the remnants of

\section{RenFrew, Phylakopi, p. 370-373.}

28 KN Xd 97; PY An 607. 5; Cn 1287. 6; Tn 316.

29 Renfrew, Phylakopi, p. 440-441.

30 Our understanding of the relatively painless transition from Mycenaean to Greek religion has been enhanced by the recent demonstration that the IonicAttic calendar descended from the Mycenaean which, significantly for our understanding of contemporary cult, had been based on agrarian seasonal festivals and therefore already included intercalary periods of the solar year in the second millennium B. C. The link was discussed by S. HILLER \& O. PANAGL, Die frühgriechischen Texte aus mykenischer Zeit, Darmstadt, 1976, p. 313, and has now been shown in detail by C. TRÜMPEL, Nochmals $z u$ den mykenischen Fr-Taefelchen, in SMEA, 27 (1989), p. 230-233, who convincingly argues against Nilsson's thesis of the later introduction to Greece of the solar calendar.

31 For the Geometric/Archaic altar in the enclosure see LEBESSI-MUHLY, in $A A$ (1990), p. 324-328. The special problems regarding variations in the sacrificial procedure cannot be discussed here.

32 Cf. GESELL, Town, p. 62.

33 RutKowski, Cult Places, p. 219; 222 with modern refs. 
'peak' cult at Epidaurus ${ }^{34}$, older religious traditions also endured on the mainland ${ }^{35}$. The Mycenaeans took home with them the potent sign of the double axe, albeit in less and less practical form; but in myth and cult it arguably still conveyed the same primary message of renewal ${ }^{36}$.

The new cult assemblage of IIIB occurred in independent shrines including the time honoured cave at Patsos ${ }^{37}$. Very occasionally the goddess was modelled in a kind of hut-urn or humble 'naiskos', which had no parallel on the mainland, although the Mycenaeans might have been familiar with the prototype of this shrine in Ugarit/Ras Shamra ${ }^{38}$. However, with her arms upraised in a gesture of benediction or as a sign of epiphany ${ }^{39}$, she was a Mycenaean goddess with a Minoan ancestry: stylistically she represented the end product of repeated Minoan / Mycenaean cross fertilization ${ }^{40}$. The male derived from the eastern Warrior- or Smiting god whose image appeared all over the Aegean at the time ${ }^{41}$. The male's eastern guise concealed a mixture of both oriental and western religious components. The warlike image constituted the visual expression of a male divinity in anthropomorphic form. There is no guarantee that he was exclusively Mycenaean or an imported god. Iconography merely provided his physical shape, no more

34 V. LAMBrinoudakis, Remains of the Mycenaean Period in the Sanctuary of Apollo Maleatas, in Sanctuaries, p. 59-65; DIETRICH, Tradition, p. 28; 44; 54; $139 ; 140$.

35 See DieTrich, Tradition, p. 1-40 for examples.

36 See n. 26. However, for Renfrew's thesis that religious symbols lost or changed their message see Phylakopi, p. 367-368; 394-395; 396.

37 J. BoARdman, The Cretan Collection in Oxford. The Dictaean Cave and Iron Age Crete, Oxford, 1961, pl. 25; J. BouzEK, Syrian and Anatolian bronze age figurines in Europe, in Proceedings of the Prehistoric Society, 38 (1972), p. 156 $164, \mathrm{n}^{\circ}$ 8; O. NEGBI, Canaanite Gods in Metal, an archaeological study of ancient Syro-Palestinian figurines, Tel Aviv, 1976, $\mathrm{n}^{\circ} 1406$; D. Collon, The Smiting God: a study of bronze in the Pomerance Collection in New York, in Levant, 4 (1972), p. 124 n 3; RenFrew, Phylakopi, p. 306; 308; 439; RUTKowski, Cult Places, p. 70.

38 R. HÄGG, The Cretan Hut Models, in OAth, 18 (1990), p. 95-107. On the eastern prototype see S. AlEXIOU, in KChr, 12 (1958), p. 279 n. 392; HÄGG, ibid , p. 100.

39 'Segensgestus', F. SCHACHERMEYR, Die minoische Kultur des alten Kreta, Stuttgart, 1964, p. 144; cf. RENFrEw, Phylakopi, p. 432, a 'general attribute of holiness'.

40 Renfrew, Phylahopi, p. 432-433; 437.

41 For discussion \& refs. see DieTRICH, Tradition, p. 21-22. 
or less; but the god's anthropomorphic figure became a popular subject for the coroplast at the time in Greece as well as in Crete, at Vrokastro and of course in the famous Apollo of Dreros ${ }^{42}$. The type continued into Geometric in Crete and Greece ${ }^{43}$, providing an artistic model for the 8th/7th century B.C. bronzes in Olympia 44 and indeed the archaic sculptures of the striding Zeus or Poseidon ${ }^{45}$.

It is of course convenient to identify the trend with a dramatic change in religious direction, away from a central Minoan goddess to a dominant Mycenaean male figure; but this involves a literal interpretation of artistic convention. Gods in human shape are notoriously difficult to detect in Minoan and Mycenaean art ${ }^{46}$, while large anthropomorphic cult images seem to have been absent altogether ${ }^{47}$. Partly this may be explicable through a major revelationary element in Minoan religion which allowed deities to be ritually invoked and appear directly to their worshippers in a kind of ideal Homeric setting 48 . However, Minoans and Mycenaeans were no iconoclasts, for them divine power more readily manifested itself in zoomorphic and aniconic form

42 Gesell, Town, p. 67 \& Pl. 60.

43 RENTREW dates the Cretan bronzes to IIIC rather than later, Phylakopi, p. 437.

44 B. АLRотн, Greek Gods and Figurines, Uppsala, 1989, p. 36-41.

45 Cf. W. BURKERT, Reshep-Figures, Apollon von Amyklai und die "Erfindung" des Opfers auf Cypern, in GB, 4 (1975), p. 64; RENFREW, Phylakopi, p. 307.

46 Judging from the criteria of size and compositional position, the figure of a goddess was dominant with the possible exception of the 15th century B. C. socalled Master Impression from Khania, E. HALLAGER, The Master Impression, Göteborg, 1985.

47 N. MARINATOS \& R. HÄGG, Anthropomorphic Cult Images in Minoan Crete?, in Minoan Society (Procs. of the Cambridge Colloquium 1981), O. KRzYsKowsKA \& L. NIXON eds., Bristol C.P., 1983, p. 185-201. The seated figure receiving offerings on a fresco from Xeste 3 in Thera may have depicted the actual or prayed for epiphany of a goddess, P. WARREN, Minoan Religion as Ritual Action, Gothenburg, 1986 (10th Felix Neubergh Lecture), p. 32; cf. N. Marinatos, Art and Religion in Thera. Reconstructing a Bronze Age Society, Athens, 1984, p. 61-62, Fig. 40.

48 On the much discussed topic of epiphany see NILSSON, $M M R^{2}$, p. 341-388; F. MatZ, Göttererscheinung und Kultbild im minoischen Kreta, Wiesbaden, 1958; R. HÄGG, Die götttliche Epiphanie im minoischen Ritual, in MDAI(A), 101 (1986), p. 41-62. 
lacking any obvious signs of gender to the modern observer ${ }^{49}$. It is not inconceivable then that in this kind of setting a male element enjoyed equal rights.

A recent study constructs a plausible system on this basis. In it Minoan divine power appeared in human, animal and material guise: double axe, horns of consecration, bird, snake, pillar and tree on their own, or in elaborate combinations, symbolised both the male and female divine elements whose life-giving hieros gamos lay at the heart of Minoan religion ${ }^{50}$. If this is substantially correct, the emergence of an oriental type male figure shows a growing predilection for divine representation in human form. Whether the transformation of style was accompanied by a change in the conception of divine power, is another matter altogether which cannot be decided by a study of the iconography alone.

The introduction of large scale single anthropomorphic cult images by the end of the 8th century B.C. provides an illuminating example of one artistic form concealing different notions of divinity. The Egyptian model physically conceptualised the god himself, while the Greek sculptor saw the perfect human form in his work as an ideal with which to honour the god. The statue was an agalma, or gift, and quite distinct from the simple cult image whose power had not changed since Mycenaean times. Pheidias' splendid Athena Promachos on the acropolis like its temple was an expression of Athenian political influence and as far removed from the cult image in spirit as from the votive figurines in form ${ }^{51}$. His seated figure of Zeus in Olympia, according to Livy ${ }^{52}$, created an overwhelming but unhellenic impression on Aemilius Paulus, comparable by some stretch of the imagination with what a visitor from a lesser culture might have felt on seeing the great palace of Knossos.

In sum the continuity into historical Greece of Mycenaean religion is now well established. Its relationship with the earlier Minoan culture at the end of the palace period should also be judged positively in the light

49 E.g. Nilsson, $M M R^{2}$, p. 58; 258; Dietrich, Origins, p. 81-82; W ARREN, Minoan Religion, p. 32.

50 Pötscher, Aspekte, p. $17-66$ (double axe); $67-79$ (horns of consecration), and passim.

51 ALROTH, Gods, p. 54.

$5245,28,5$. 
of considerable uniformity between the two cultures. The palace's economic and political importance overshadowed its religious role, so that the end of the palace system in Crete and on the mainland in LBA IIIB had less effect on religious traditions than is commonly assumed. Iconographic transformations more faithfully reflect changes in artistic fashion than novel forms of divine conception. Minoan/ Mycenaean pictures do not tell the whole story: they may well present a distorted view of actual cult and cult figures.

B.C. DIETRICH

University of Wales

ABERYSTWYTH 